УДК 338.43:331

Лазарєва О.В., доктор економічних наук, професор, професор кафедри управління земельними ресурсами

O. Lazarieva, Doctor of Economic Sciences, Professor, Professor Department of the landed resources management https://orcid.org/0000-0002-1050-7118

\title{
ЕКОНОМКА ЗЕМЛЕУСТРОЮ В КРАЇНАХ ЄВРОПЕЙСЬКОГО СОЮЗУ: ОСОБЛИВОСТІ ТА МОЖЛИВОСТІ АДАПТАЦЇ̈ ДО УКРАЇНСЬКОГО ПРОСТОРУ
}

\author{
Чорноморський національний університет імені Петра Могили
}

В статті проаналізовані питання, пов'язані з успішністю ведення економіки землеустрою. Ціллю дослідження $\epsilon$ вивчення основних аспектів здійснення економіки землеустрою в країнах ЄС та на цій основі обгрунтування перспектив здійснення економіки землеустрою в Україні.

Проаналізовано досвід орендних відносин, грошової оцінки, переоцінки землі. Діагностовано ціни на земельні ділянки в європейських країнах.

Вивчено такий метод економіки землеустрою як економічне стимулювання. 3'ясовано, що він в основному стосується надання різноманітних субсидій і прямих виплат фермерам на дотримання ними стандартів охорони земельних ресурсів. Вивчення пріоритетів здійснення економіки землеустрою в країнах Євросоюзу дозволило окреслити можливості ії адаптації до українського простору.

Встановлено, що основними показниками економіки землеустрою є структура земельних угідь, питома вага сільгоспугідь та ріллі в загальній площі, питома вага ріллі та багаторічних насаджень в сільгоспугіддях, питома вага умовної площі в площі сільгоспугідь, структура посівів, середньорічна чисельність робітників на 100 га сільгоспугідь (трудозабезпеченість), фондооснащеність (фондозабезпеченість), фондо- та енергоозброєність, відносні затрати на внутрігосподарський землеустрій, відносна величина витрат на проектні вишукувальні роботи по землеустрою, капітальні вкладення по організації території.

3'ясовано, що основними перспективами здійснення економіки землеустрою в українських реаліях є обов'язкова розробка схем землеустрою і техніко-економічне обгрунтування використання та охорони земель, запровадження повноцінного ринку землі, стратегічне планування використання земель, визначення вартості земельних ділянок, виходячи 3 рівня окупності витрат культур, справедливе визначення нормативної грошової оцінки землі, залучення іноземних інвестицій, надання кредитної підтримки малому та середньому бізнесу, обов'язкове визначення показників економіки землеустрою.

Ключові слова: економіка землеустрою, землеустрій, грошова оцінка земельних ділянок, ціна землі, вартість землі, економічне стимулювання, ефективність землеустрою, ринок землі.

\section{ECONOMY OF LAND MANAGEMENT IN THE COUNTRIES OF THE EUROPEAN UNION: FEATURES AND POSSIBILITIES OF ADAPTATION TO THE UKRAINIAN SPACE}

\author{
Petro Mohyla Black Sea National University
}

The article analyzes the issues related to the success of land economics. The aim of the study is to study the main aspects of land economics in the EU and on this basis to substantiate the prospects of land economics in Ukraine.

The experience of lease relations, monetary valuation, land revaluation is analyzed. Diagnosed land prices in European countries.

The method of land management economics as economic stimulation is studied. It was found that it mainly concerned the provision of various subsidies and direct payments to farmers for their compliance with land protection standards. It is focused on the fact that in Western Europe the economic stimulation of environmental and land protection measures is carried out through soft loans, subsidies and interest-free loans for the purchase of environmentally friendly equipment, grace periods for depreciation of environmental funds, tax exemptions for income tax. projects, price incentives for the production of environmentally friendly products. 
The research revealed that the economics of land management is a science of rational and efficient use of land resources, the organization of land protection and increase its fertility.

The study of the priorities of land management in the European Union allowed to outline the possibilities of its adaptation to the Ukrainian space.

It is established that the main indicators of land management economy are the structure of land, the share of agricultural land and arable land in total area, the share of arable land and perennial plantations in agricultural land, the share of conditional area in agricultural land, crop structure, average annual number of workers per 100 workers. ), capital equipment (capital security), capital and energy equipment, relative costs of on-farm land management, the relative value of costs for project survey work on land management, capital investments in the organization of the territory. To determine the effectiveness of the land management project should calculate the value of marketable products that were produced at the time of the project and which will be produced by the project and material costs for crop and livestock production and humus balance at the time of the project and the project.

It was found that the main prospects for land economics in the Ukrainian reality are the mandatory development of land management schemes and feasibility study of land use and protection, the introduction of a full land market, strategic land use planning, determining the value of land based on cost recovery crops, fair definition of normative monetary valuation of land, attraction of foreign investments, provision of credit support to small and medium business, obligatory determination of indicators of land management economy.

Key words: land management economics, land management, monetary valuation of land plots, land price, land value, economic incentives, land management efficiency, land market.

Постановка проблеми у загальному вигляді i ïi зв'язок 3 важливими науковими та практичними завданнями. Враховуючи перехід України до світового економічного простору, роль економіки землеустрою в контексті вивчення іiі євроінтеграційних перспектив посідає особливе місце. В цих умовах формування ефективної системи ведення економіки землеустрою з урахуванням європейських перспектив є невід'ємною частиною раціоналізації землекористування, що підвищує продуктивність землі та стійкість національної економіки.

Оскільки однією із головних задач землеустрою $є$ організація ефективного використання землі, то й відповідно здійснюється взаємодія основних факторів виробництва, а саме землі, праці та матеріально-технічних ресурсів. Це потребує необхідності вивчення питань, що стосуються ведення економіки землеустрою, а також забезпечення раціонального використання земельних, трудових та матеріальних ресурсів при розробці проектів землеустрою.

Аналіз останніх досліджень, у яких започатковано вирішення проблеми. В наукових джерелах сьогодні майже не зустрічаються наукові праці, в яких досліджується питання саме сутності економіки землеустрою. Зустрічаються лише поодинокі випадки. Так, А.М. Третяк економіку землеустрою [1, с. 9] розуміє як відносини людей в процесі землевпорядної діяльності щодо пошуку, узгодження інтересів та прийняття ефективних рішень із планування використання та охорони земельних ресурсів та організації території землеволодінь та землекористувань.

Стосовно трактування землеустрою, то вивченням цього питання займались різні вчені. Так, Г.І. Грещук [2] стверджує, що поняття землеустрій доцільно вживати, коли мова йде про заходи, які направлені на регулювання земельних відносин та організацію певних територій. Д.С. Добряк [3] висловлює думку, що землеустрій є основоположним механізмом регулювання земельних відносин, що має відповідне законодавче забезпечення. І.В. Шарко [4] землеустрій розуміє як процес, що забезпечує повноту досягнень прикладних досліджень, які охоплюють питання еколого-економічної та соціальної ефективності землекористування, зростання вартості земельного капіталу та формування ринкової інфраструктури. П.Т. Казьмір [5] трактує землеустрій як складний соціально-економічний процес, що реалізується через механізм інженерно-технічних, організаційних, екологічних і земельно-правових заходів, які знаходяться у тісному взаємозв'язку та відображаються в землевпорядних розробках. Й.М. Дорош [6] 
стверджує, що землеустрій є системоутворюючим фактором формування земельних відносин. Потре в сучасних реаліях потребують висвітлення перспективи здійснення економіки землеустрою в українську економіку 3 урахуванням європейських пріоритетів.

Цілі статті. Відповідно ціллю дослідження $є$ вивчення основних аспектів здійснення економіки землеустрою в країнах $\mathrm{CC}$ та на цій основі обгрунтування перспектив здійснення економіки землеустрою в Україні.

Виклад основного матеріалу дослідження 3 повним обгрунтуванням отриманих наукових результатів. У більшості країн Західної Європи однією 3 форм використання земель $є$ оренда. Так, у Бельгії більше $70 \%$ земель перебуває в оренді, у Німеччині та Франції - понад 60 \%, у Нідерландах - 35 \% земель [7, с. 68].

У Франції діє Департамент по управлінню землею. Крім того, у Франції функціонує некомерційна корпорація, діяльність якої зводиться до управління сільськогосподарськими землями від імені держави [8]. В Німеччині діє федеральний закон про територіальне планування, існує закон по інфраструктурному плануванню. Муніципалітети в межах федерального закону здійснюють територіальне планування i розробляють Генеральні плани будівництва, в межах яких складається план використання земельних ділянок і план забудови [9].

Що стосується грошової оцінки земельних ділянок, то у країнах Євросоюзу вартість земель визначається із розрахунку показника продуктивності або шляхом встановлення іiі реальної ринкової вартості згідно із цінами купівлі-продажу земельної ділянки [10, с. 130].

У Великобританії застосовуються два методи оцінки земель: на основі потенційної та на основі фактичної продуктивності грунтів [11].

У Німеччині основою для оцінки вартості землі є оцінка реальної вартості ділянки, яка передбачає визначення якості грунтів, оцінку родючості землі, врахування місця розташування земельної ділянки, віддаленості від основних магістралей, рівень цін, заробітної плати [12].

В країнах Європи регулярно проводиться переоцінка землі, що зумовлено тим, що iii ринкова вартість може змінюватись. При цьому середній чистий дохід, що дає земельна ділянка, визначається в цілому за останні 5 років [13].

У Польщі вартість 1 га землі визначається як добуток вартості за 1 ц житв в оціночну ставку одного гектара. Відповідно встановлюється і податок на землю, враховуючи при цьому вид і клас земель.

У таких європейських країнах, як Угорщина, Румунія, Чехія та Словаччина оцінка земель розпочинається з бонітування, в основу якого покладені такі чинники як грунт, клімат, рельєф.

В Іспанії оцінка земельних ділянок сільськогосподарського призначення передбачає наявність трьох таких етапів як визначення списку вирощуваних культур на рівні регіону та оцінка інтенсивності їх вирощування; доведення розробленої раніше шкали оцінки до рівня муніципалітету з огляду на його специфічні природні і грунтові умови; індивідуальна оцінка земельних ділянок [14].

У Швеції для оцінки земель сільгосппризначення спочатку несільськогосподарські землі оцінюють за ринковою вартістю (методом порівняння продажів), а сільськогосподарські - за капіталізованим чистим прибутком (методом земельної ренти, чому передує агрокліматична оцінка [14].

У Франції вартість землі оцінюється 3 врахуванням продуктивності сільськогосподарського використання, визначається за врожайністю сільськогосподарських культур з урахуванням затрат. Завершальним етапом оцінки $є$ їх розподіл за класами, про що інформація розміщується у кадастрових матрицях [15, с. 22]. 
Найвищі ціни на земельну ділянку зафіксовані в Нідерландах - 60 тис дол за гектар. У більшості ж західноєвропейських країн ціни коливаються в межах від 15 до 30 тис дол з гектар, а в Східній Європі - від 1 до 5 тис дол за гектар [16, с. 138]. У Франції та Німеччині ціни за один гектар землі коливаються від 10 до 12 тис євро [17, с. 588]. При проведенні оцінки беруться до уваги такі показники, як ступінь інтенсивності ведення сільськогосподарської діяльності, структура та тип грунту.

Оцінюючи в цілому міжнародний довід оцінки землі в країнах Свропи, зауважимо, що він грунтується на Європейських стандартах оцінки (European Valuation Standards), які розробляються Свропейською групою оцінювачів основних фондів.

Заслуговує на увагу і такий метод охорони грунтів в країнах $\mathrm{CC}$, як економічне стимулювання, що реалізується в рамках САП (Спільної аграрної політики). Це стосується в першу чергу надання різноманітних субсидій і прямих виплат фермерам на дотримання ними стандартів охорони земельних ресурсів. Так, наприклад, у Німеччині, землевласники обов'язково мають враховувати регіональні природно-кліматичні умови господарювання, поліпшувати структурний склад грунту та запобігати його ущільненню, дбайливо ставитись до природних ландшафтів [18].

Взагалі в країнах Західної Свропи економічне стимулювання природоохоронних та землеохоронних заходів здійснюється за допомогою пільгового кредитування, надання субсидій та безвідсоткових позик на придбання екологобезпечного обладнання, пільгових строків амортизаційного списання природоохоронних фондів, звільнення від податків частини прибутків, що спрямовується на природоохоронні об'єкти, цінове стимулювання виробництва екологічно чистої продукції, компенсація 50 \% втрат, що зумовлені залуженням та залісненням. Крім того, в країнах ЄС отримав розповсюдження такий метод швидкого космічного супутникового спостереження за земельним фондом, який дозволяє контролювати стан ріллі, пасовищ, садів і виноградників [19].

В цілому проектування землеустрою в країнах $Є С$ свідчить, що політика розвитку землекористування грунтується на Єдиній політиці Європейського Союзу, а проектування землеустрою здійснюється у разі необхідності створення нового землеволодіння або зміни меж вже існуючих, в процесі проектування землеволодінь, удосконалення технологій виробництва тощо [20].

Вивчення пріоритетів здійснення економіки землеустрою в країнах Євросоюзу дозволило окреслити можливості її адаптації до українського простору.

Враховуючи, що землеустрій являє собою сукупність соціально-економічних та екологічних заходів, спрямованих на регулювання земельних відносин та раціональну організацію території адміністративно-територіальних утворень, суб'єктів господарювання, що здійснюються під впливом суспільно-виробничих відносин i розвитку продуктивних сил [21], відповідно економіка землеустрою являє собою науку про раціональне та ефективне використання земельних ресурсів, про організацію охорони землі та підвищення iї родючості. Предметом же економіки землеустрою $\epsilon$ система організаційно-економічних та виробничих відносин, що регулюють процеси використання та охорони земель 3 метою підвищення їх ефективності та сприяють обгрунтуванню землевпорядних рішень. Відповідно економіка землеустрою являє собою науку про раціональне та ефективне використання земельних ресурсів, про організацію охорони землі та підвищення ії родючості.

В українських реаліях інноваційність землеустрою полягає в унормуванні відносин між органами державної влади та органами місцевого самоврядування, суб'єктами господарювання на землі, інвесторами, визначає стратегію розвитку землекористування, що забезпечує його конкурентоспроможність, адаптує території до вимог ринкової економіки та відкритого конкурентного ринку [22]. 
На нашу думку, основними показниками економіки землеустрою є структура земельних угідь, питома вага сільгоспугідь та ріллі в загальній площі, питома вага ріллі та багаторічних насаджень в сільгоспугіддях, питома вага умовної площі в площі сільгоспугідь, структура посівів, середньорічна чисельність робітників на 100 га сільгоспугідь (трудозабезпеченість), фондооснащеність (фондозабезпеченість), фондота енергоозброєність, відносні затрати на внутрігосподарський землеустрій, відносна величина витрат на проектні вишукувальні роботи по землеустрою, капітальні вкладення по організації території.

Узагальнюючі ж показники ефективності землеустрою відображають його екологічну, економічну та соціальну сторони та базуються на показниках приросту чистої продукції. До числа узагальнюючих показників необхідно віднести наступні: відношення приросту чистої продукції до затрат на проектування й виконання заходів по організації території, що потребують капітальних вкладень протягом розрахункового періоду; відношення приросту чистої продукції, отриманої за рахунок землеустрою, до затрат живої та уречевленої праці.

До числа узагальнюючих відносяться також і показники взаємозамінності ефекту від землеустрою та ефекту від додаткового залучення ресурсів - капіталовкладень, виробничих фондів, праці, землі.

Економічна ж ефективність проекту організації території визначається також порівняно з існуючим станом використання земель.

Для визначення ефективності проекту землеустрою доцільно розраховувати вартість товарної продукції, яка вироблялась на час складання проекту і яка буде вироблятись за проектом; матеріально-грошові затрати на виробництво продукції рослинництва і тваринництва та баланс гумусу на час складання проекту і за проектом.

Запропоновані показники економіки землеустрою дадуть змогу зробити відповідні висновки щодо сучасного стану використання сільськогосподарських угідь та організації їх території стосовно природних і еколого-економічних умов, а також дадуть змогу надати пропозиції щодо організації території і впорядкування сівозмін.

3 урахуванням вищевикладеного спробуємо надати ще й рекомендації щодо перспектив здійснення економіки землеустрою в Україні:

1) розробка схем землеустрою i техніко-економічне обгрунтування використання та охорони земель адміністративно-територіальних утворень повинно забезпечувати еколого-економічне обгрунтування сівозмін та впорядкування угідь;

2) запровадження повноцінного ринку землі повинно передбачати дотримання механізму його регулювання та ефективного обігу земельних ділянок суб'єктів господарювання, що сприятиме забезпеченню використання землі як сталого базису виробництва;

3) ведення землеустрою має передбачати стратегічне планування використання земель, що сприятиме формуванню земельних відносин ринкового типу;

4) визначення правильної вартості земельних ділянок, виходячи 3 рівня окупності витрат культур, сприятиме дотриманню екологічної придатності грунтів, що забезпечуватиме вирощування відповідного асортименту культур

5) справедливе визначення нормативної грошової оцінки землі, а також створення системи економічного стимулювання та відшкодування збитків забезпечить дотримання об'єктивних розмірів плати за землю та орендної плати;

6) економічне стимулювання та раціональне використання земельних ресурсів сприятиме залученню іноземних інвестицій, наданню кредитної підтримки малому та середньому бізнесу; 
7) обов'язковість визначення показників економіки землеустрою, що сприятиме правильній організації території та впорядкуванню сівозмін відповідно до потреб господарюючих суб' єктів.

Розглянуті вище перспективи здійснення економіки землеустрою представлені на рис. 1.

\section{ЕКОНОМГКА}

розробка схем землеустрою і техніко-економічне обгрун-тування використання та охорони земель
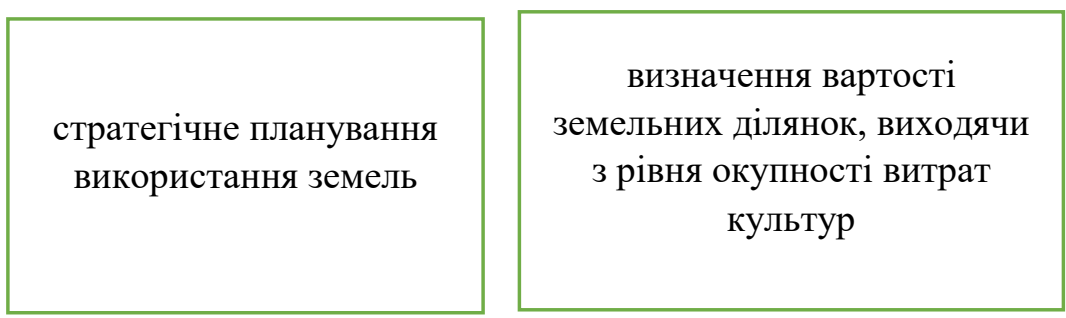

запровадження повноцінного ринку землі

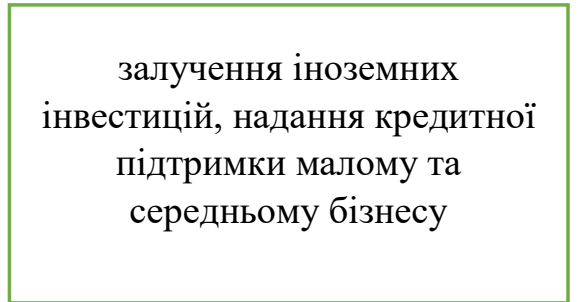

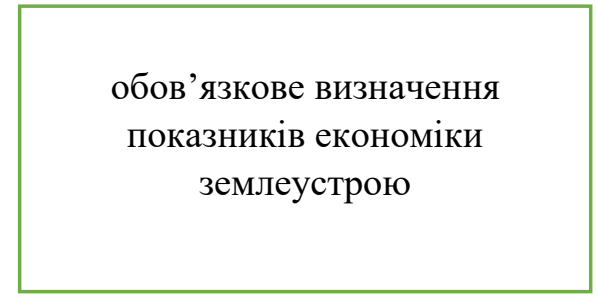

ЗЕМЛЕУСТРОЮ справедливе визначення нормативної грошової оцінки землі

Рис. 1. Перспективи здійснення економіки землеустрою в українському просторі Джерело: Складено автором

Забезпечення дотриманих вище перспектив ведення економіки землеустрою сприятиме гармонізації українського економічного простору відповідно європейських пріоритетів.

Висновки. В процесі дослідження вивчено основні аспекти основні аспекти здійснення економіки землеустрою в країнах ЄС. 3'ясовано, що у таких країнах як Бельгія, Німеччина, Франція та Нідерланди основною формою використання землі $є$ оренда. В європейських країнах вартість земель визначається або ж із розрахунку показника продуктивності, або шляхом встановлення її реальної ринкової вартості згідно із цінами купівлі-продажу земельної ділянки. В цілому ж міжнародний довід оцінки землі в країнах Європи грунтується на Європейських стандартах оцінки.

Вивчення в цілому перспектив здійснення економіки землеустрою в європейських країнах окреслило можливості ії̈ адаптації до українських реалій. 
Основними показниками економіки землеустрою є структура земельних угідь, питома вага сільгоспугідь та ріллі в загальній площі, питома вага ріллі та багаторічних насаджень в сільгоспугіддях, питома вага умовної площі в площі сільгоспугідь, структура посівів, середньорічна чисельність робітників на 100 га сільгоспугідь (трудозабезпеченість), фондооснащеність (фондозабезпеченість), фондо- та енергоозброєність, відносні затрати на внутрігосподарський землеустрій, відносна величина витрат на проектні вишукувальні роботи по землеустрою, капітальні вкладення по організації території. Узагальнюючими ж показники ефективності землеустрою слід віднести відношення приросту чистої продукції до затрат на проектування й виконання заходів по організації території, відношення приросту чистої продукції, отриманої за рахунок землеустрою, до затрат живої та уречевленої праці.

Перспективами здійснення економіки землеустрою в українських реаліях $\epsilon$ обов'язкова розробка схем землеустрою i техніко-економічне обгрун-тування використання та охорони земель, запровадження повноцінного ринку землі, стратегічне планування використання земель, визначення вартості земельних ділянок, виходячи 3 рівня окупності витрат культур, справедливе визначення нормативної грошової оцінки землі, залучення іноземних інвестицій, надання кредитної підтримки малому та середньому бізнесу, обов'язкове визначення показників економіки землеустрою. Дотримання запропонованих вище перспектив сприятиме переходу економіки України на такий шлях розвитку, який враховуватиме позитиви європейського досвіду провідних країн.

Подальші дослідження мають бути спрямовані на обгрунтування пріоритетності здійснення наукових досліджень у сфері землеустрою.

\section{Список бібліографічного опису:}

1. Третяк А.М., Третяк В.М., Гетманьчик І.П., Гунько А.А. Поняття та сутність економіки землеустрою та землевпорядкування в Україні. Агросвіт. № 11. 2021. С. 3-10.

2. Грещук Г.І. Сутність землеустрою та землевпорядкування: концептуальний підхід. Агросвіт. № 23. 2016. С. 24-27.

3. Добряк Д.С., Кузін Н.В. Землеустрій як інструмент реабілітації деградованих земель сільськогосподарського призначення. Збалансоване природокористування. № 3. 2016. С. 116-126.

4. Шарко І.В., Ярута М.Ю. Інноваційність національної системи землекористування. Вісник ХНАУ ім. В.В. Докучаєва. Серія „Економічні науки”. № 4. Т. 2. 2019. С. 314-323.

5. Організація сільськогосподарського використання земель на ландшафтно-екологічній основі. За ред. проф. П.Г. Казьміра. Л.: СПОЛОМ, 2009. 254 с.

6. Дорош Й.М. Землеустрій як основоположний механізм формування земельних відносин в умовах трансформаційної економіки. Землеустрій, кадастр і моніторинг земель. № 1-2. 2012. С. 6-14.

7. Височанська М.Я. Зарубіжний досвід використання земельних ресурсів. Агросвіт. № 15. 2015. С. 67-72.

8. Мартин А. Г. та ін. Земельна політика європейського співтовариства: принципи, проблеми, реалізація: монографія. К.: Компринт, 2017. 159 с.

9. Наконечна К.В. Особливості земельних відносин в різних країнах світу. Ефективна економіка. № 10. 2018. URL: http://www.economy.nayka.com.ua/pdf/10_2018/65.pdf (дата звернення: 18.08.2021).

10. Коробська А.О. Державне регулювання використання земель сільськогосподарського призначення в Україні: дис. ... канд. екон. наук: 08.00 .03 - економіка та управління національним господарством (економічні науки). Подільський державний аграрно-технічний університет, Кам'янець-Подільський, 2020. 255 с.

11. Гривнак К. Застосування нормативно-грошової оцінки землі як бази оподаткування. Вісник Міністерства доходів і зборів України. 2012. № 30. URL: http://www.visnuk.com.ua/ua/magazine/id/71 (дата звернення 18.08.2021)

12. Реформування підходу до оцінки земель сільськогосподарського призначення для цілей оподаткування на підставі міжнародного досвіду. Ірпінь : НДІ фінансового права, 2014. 32 с.

13. Зінчук Т. О., Данкевич В.С. Європейський досвід формування ринку сільськогосподарських земель. Економіка АПК. 2016. № 12. С. 84-92. URL: http://nbuv.gov.ua/UJRN/E_apk_2016_12_14 (дата звернення: 18.08.2021).

14. Кадастровая оценка земли и связанной с ней недвижимости в Испании. Владимир, 1998: Ин-т оценки Земли, 1998. $111 \mathrm{c}$.

15. Дивнич А.В. Формування ринкової вартості земельних ресурсів сільськогосподарських підприємств. Технологический аудит и резервы производства. 2012. № 11(3). С. 17-22.

16. Марчук У.О. Оцінка землі у міжнародній обліковій системі. Науковий вісний Херсонського держсавного університету. Випуск 24. Частина 2. 2017. С. 138. URL: http://www.ej.kherson.ua/journal/economic_24/2/32.pdf (дата звернення: 19.08.2021).

17. Кошель А. О. Міжнародний досвід оцінки та оподаткування земель сільськогосподарського призначення. Глобальні та національні проблеми економіки. 2015. - № 6. - C. 588-590. URL: http://global-national.in.ua/archive/62015/119.pdf (дата звернення: 18.08.2021). 
18. Держсільгоспінспекція впроваджує механізм охорони земель на досвіді Німеччини. Офіційний сайт Держсільгоспінспекції України. URL: http: www.disgu.gov.ua/index.php?start=315 (дата звернення 19.08.2021).

19. Андрущенко А.В. Економічне стимулювання раціонального використання та охорони земель сільськогосподарського призначення. URL: http://base.dnsgb.com.ua/files/journal/Visnyk-Lvivskogo-Nats-agraruniver/APK/2010_1/files/10aapoal.pdf (дата звернення 19.08.2021).

20. Dumanski J. International Workshop on Sustainable Land Management for the $21^{\text {st }}$ Century: Summary. Workshop Proceedings. Agricultural Institute of Canada, Ottawa, ON. 1994. 50 p.

21. Закон України «Про землеустрій» від 22.05.2003 № 858-IV. URL: https://xn--80aagahqwyibe8an.com/ukrajinyzakony/zakon-ukrajini-pro-zemleustriy-vidomosti2003.html (дата звернення: 19.09.2021).

22. Лазарєва О.В. Інноваційний характер розвитку сучасного землеустрою. Економічний часопис Східноєвропейського національного університету імені Лесі Українки. № 1. 2018. C. 81-87. URL: https://www.researchgate.net/publication/324770227_Innovative_character_of_development_of_modern_organization_of_th e_use_of_the_land/fulltext/5b3c29694585150d23f67899/Innovative-character-of-development-of-modern-organization-of-

the-use-of-the-land.pdf (дата звернення 19.08.2021).

\section{References:}

1. Tretiak, A., Tretiak, V., Hetmanchyk, I. and Hunko, L. (2021), The concept and essence of the economy of land organization and land planning in Ukraine, Agrosvit, vol. 11, pp. 3-10.

2. Hreschuk, G. (2016), The essence of land management: the conceptual approach, Agrosvit, vol. 23, pp. 24-27.

3. Dobryak, D.S., Kuzin, N.V. (2016). Land management as a tool for rehabilitation of degraded agricultural lands. Zbalansovane prirodokoristuvannya. № 3. pp. 116-126.

4. Sharko, I.V., Yaruta, M.O. (2019). Innovativeness of the national land use system. Visnyk HNAU im Dokuchaeva. Seria «Economic science». № 4. T. 2, pp. 314-323.

5. Kazmir P.T. (2009). Organization of agricultural land use on a landscape-ecological basis. L. Spolom, 254 p.

6. Dorosh, Y.M. (2012). Land management as a fundamental mechanism for the formation of land relations in a transformational economy. Zemleustry, kadastr I monitoring zemel. № 1-2, pp. 6-14.

7. Visochanska, M.Ya. (2015). Foreign experience in land use. Agrosvit, vol. 15, pp. 67-72.

8. Martyn, A.G. and others. (2017). Land policy of the European community: principles, problems, implementation. Monografia. K.: Kompprint, 159 p.

9. Nakonechna, O.O. (2018). Features of land relations in different countries. Efektyvna ekonomika. № 10. Available at: http://www.economy.nayka.com.ua/pdf/10_2018/65.pdf (accessed 18.08.2021).

10. Korobska, A.O. (2020). State regulation of agricultural land use in Ukraine. Cand. Thesis. Podolsk State Agrarian Technical University: Kamenets-Podolsky. 255 p.

11. Grivnak, K. (2012). Application of normative-monetary assessment of land as a tax base. Visnyk Ministerstva dohodiv I zboriv Ukrayny. № 30. Available at: http://www.visnuk.com.ua/ua/magazine/id/71 (accessed 18.08.2021).

12. Reforming the approach to the valuation of agricultural land for tax purposes based on international experience. (2014). Irpin: NDI finansovogo prava. $32 \mathrm{p}$.

13. Zinchuk, T.O., Dankevich, V.E. (2016). European experience of agricultural land market formation. Ekonomika APK. № 12, pp. 84-92. Available at: http://nbuv.gov.ua/UJRN/E_apk_2016_12_14 (accessed 18.08.2021).

14. Cadastral valuation of land and related real estate in Spain. (1998). Vladimir. In-t ocenky zemly. $111 \mathrm{p}$.

15. Divnich, A.V. (2012). Formation of the market value of land resources of agricultural enterprises. Tehnologichesky audit I rezervy proizvodsyva. № 11(3). pp. 17-22.

16. Marchuk, U.O. (2017). Land valuation in the international accounting system. Naukovy visnik Hersonskogo dergavnogo universitetu. Vipusk 24. Chastyna 2. P. 138. Available at: http://www.ej.kherson.ua/journal/economic_24/2/32.pdf (accessed 19.08.2021).

17. Koshel, A.O. (2015). International experience of assessment and taxation of agricultural lands. Global and national problems or economy. № 6. pp. 588-590.

18. The State Agricultural Inspectorate is implementing a land protection mechanism based on the German experience. Available at: http: www.disgu.gov.ua/index.php?start=315 (accessed 19.08.2021).

19. Andrichenko, A.V. Economic stimulation of rational use and protection of agricultural lands. Available at: http://base.dnsgb.com.ua/files/journal/Visnyk-Lvivskogo-Nats-agrar-univer/APK/2010_1/files/10aapoal.pdf (accessed 19.08.2021).

20. Dumanski J. International Workshop on Sustainable Land Management for the 21st Century: Summary. Workshop Proceedings. Agricultural Institute of Canada, Ottawa, ON. 1994. 50 p.

21. About land management. Zakon Ukrainy 2003, № 858-IV. Available at: https://xn--80aagahqwyibe8an.com/ukrajinyzakony/zakon-ukrajini-pro-zemleustriy-vidomosti2003.html (accessed 19 August 2021).

22. Lazarieva, O.V. (2018). Innovative nature of modern land management development. Economic Journal of the Lesya Ukrainka East European National University. № 1. pp. 81-87. Available at: https://www.researchgate.net/publication/324770227_Innovative_character_of_development_of_modern_organization_of_th e_use_of_the_land/fulltext/5b3c29694585150d23f67899/Innovative-character-of-development-of-modern-organization-ofthe-use-of-the-land.pdf (accessed 19.08.2021).

$$
\text { Дата подання публікації 19.08.2021 p. }
$$

